Research Paper

\title{
International Humanitarian Law and Military Intervention: Reflections on Operation Allied Forces in the Former Federal Republic of Yugoslavia in 1999
}

\author{
Pedzisai Sixpence ${ }^{1}$, Alouis Chilunjika ${ }^{1}$ \\ ${ }^{1}$ Midlands State University, P.O. Box 100 Buchwa Road, Zvishavane, Zimbabwe.
}

Article History

Received:

02.08 .2020

Revised:

10.09.2020

Accepted:

19.09.2020

*Corresponding Author:

Alouis Chilunjika

Email:

chilunjika@gmail.com

This is an open access article, licensed under: $\mathrm{CC}-\mathrm{BY}-\mathrm{SA}$

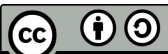

Abstract: Military intervention is a crucial tool used to compel nation states to abide by the principles of international law. The United Nations, through its Charter (Chapter VII) authorises the use of force by the UN and or regional organisations as a legitimate scheme of settling international disputes. A closer look on the majority of these interventions, however, shows that the conduct of the forces taking part in these interventions turn to violate some crucial principles of international law. Additional Protocol 1 of 1977 to the 1949 Geneva protocols provides for the regulations in terms of the conduct of forces in an armed conflict to minimise civilian carnage and injuries as well as damage on civilian objects. This paper assessed the effectiveness of International Humanitarian Law (IHL) in cases of a military intervention. The study was a case study focusing on the experiences of the North Atlantic Treaty Organisation (NATO) forces that intervened in the former Federal Republic of Yugoslavia (FRY) in 1999. The study depended on secondary sources of information. The paper reveals that forces taking part in these operations normally harm civilian population and objects beyond reasonable proportion if they do not pay attention to the details on the ground. The paper then recommends that more should be done to uphold and adhere to the provisions of Chapter VI of the UN Charter while ensuring that forces taking part in military interventions are parties to key international legislations that govern their conduct to prevent states from purposefully violate the law.

Keyword: Federal Republic of Yugoslavia, International Humanitarian Law, Military Intervention, NATO, Operation Allied Forces. 


\section{Introduction}

Sullivan and Koch [1] defines military interventions as referring to, "the use of armed forces that involves the official deployment of at least 500 regular military personnel (ground, air or naval) to attain immediate political objectives through action against a foreign adversary." To this end, Chapter VII of the United Nations (UN) Charter authorises the use of force as an option for settling disputes. Resultantly, major powers and prestigious military alliances have utilised and at times abused the provision of Chapter VII of the UN Charter to intervene militarily in different cases world-over. Koch [1] alluded that between 1945 and 2003, Britain, China, France, Russia and the USA conducted a total of 126 military interventions. Of these, the USA was leading with a total of 35 followed by France which conducted 29.

One such intervention occurred in 1999 between 24 March and 9 of June 1999 when NATO forces were in the FRY on a humanitarian military campaign. The campaign started following the intensification of the systematic cleansing of the ethnic Albanians by the Serbian military and police forces for nearly a decade since the self-proclamation of independence by the province of Kosovo from the FRY in 1998 [2]. The operation was initiated with 214 American aircraft and an additional 130 aircraft from other NATO members [3], [4]. During the period, 13 of the 19 NATO members flew more than 38, 000 sorties [5], [6] and released 23600 air munitions against over 900 targets [5]. More than 500 civilians died while around 6000 others were injured [7].

The province of Kosovo and Vojvodina, Serbia proper and Montenegro were the official targets that saw the bombing of air fields, air defence, emplacements; bridges; command, control and communication sites; and police and troops barracks [5]. The operation was only stopped on the $9^{\text {th }}$ of June 1999 after NATO and FRY officials had concluded a Military Technical Agreement (MTA) under which the Serb's police and paramilitary groups were to leave Kosovo while the NATO-led military force code-named Kosovo Force (KFOR) took control over Kosovo [6].

The United Nations Mission in Kosovo (UNMIK) was at the same point established to administer the territory with more than 20, 000 peacekeeping force being deployed under the provisions of the 1999 United Nations Security Council Resolution (UNSCR) 1244 [8].

During the bombing campaign, it can be argued, IHL was violated in many ways beyond the expectation of many. This is so because the number of civilians who died during this operation, can be regarded as being disproportional.

This paper, thus, sought to assess the effectiveness of IHL in cases of military interventions by reflecting on the experiences of the FRY during this military intervention. To achieve this, the study focused on means and methods of warfare as well as the weaponry used by the NATO in this military intercourse to appreciate the extent to which NATO adhered to the principles of humanity in Kosovo.

\section{Conceptualising Military Interventions and International Humanitarian Law (IHL)}

The concepts making up the framework for this study were the International Humanitarian Law (IHL) and Military Intervention. McCoubrey [9] defines IHL as the "branch of the laws of armed conflict concerned about the protection of victims of armed conflicts." The study acknowledged the general work of Hennri Dunant as well as the philosophical influence of St Augustine and St Thomas Aquinas to understanding the aims of the IHL in military interventions. Although the works of these philosophers covered a broader scope to include the jus ad bellum, and the jus in bello, IHL, as it was considered in this study, linked much with one of St Thomas Aquinas' criteria for a Just War, "limitation of action to the satisfaction of the original cause without pursuit of excess" [9]. The research in this regard considered the aim of military intervention to assess the objectivity of the means and methods employed in war without focusing on the legality of the intervention.

This study, therefore, included, from the Geneva Law point of view: the 1864 Geneva Convention for the Amelioration of the Condition of the Wounded in Armies in the field (ibid. 11); 1907, 1929 and the 1949 Geneva Conventions; and the 1977 and 2005 Additional Protocols [10].

On the part of the Hague law of the IHL, the study considered multilateral agreements such as the Nuclear Non-Proliferation Treaty; the 1868 Declaration of St Petersburg interdiction on the use of projectiles in war; the 1929 Geneva Convention upon Gaseous, Poisonous and asphyxiating Weapons; and the 1981 UN Convention on the use of Certain Conventional Weapons which are unpredictable to $\mathrm{x}$-ray when logged in the body [9], [11]. 
Pedzisai Sixpence, Alouis Chilunjika.

International Humanitarian Law and Military Intervention: Reflections on Operation Allied Forces in the Former Federal Republic of Yugoslavia in 1999.

International Journal of Law and Public Policy, vol. 2, no. 2, pp. 38-46, September 2020. DOI: 10.36079/lamintang.ijlapp-0202.132

\section{UN Charter and the use of force}

Akehurst [12] notes that states, as members of the UN are, according to Article 2(3) of the UN Charter, obliged to, "settle their disputes by peaceful means in such a manner that international peace and security, and justice, are not endangered".

\section{Discrimination and Proportionality}

- Principle of discrimination

Parties to a conflict are obliged to direct their operations against military objects and spare civilian population and civilian objects [13]. Military objects in this case are those objects which by nature, location, purpose or use make an effective contribution to the military action and whose total or partial destruction, capture or neutralisation, in the circumstances ruling at that time, offers a definite military advantage to the executing force (Article 52 of Additional Protocol 1 of the 1977 Geneva Convention).

- Principle of proportionality

Derivative injuries to the civilian population cannot be ruled out during a military operation but should be proportional. Article 57(2) (ii) and (iii) of the 1977 Geneva Convention oblige parties to a conflict to:

take all feasible precautions in the choice of means and methods of attack with a view of avoiding, and in any event to minimising incidental loss of civilians and to refrain from deciding to launch an attack which may be expected to cause incidental loss of civilian life, injury, damage to civilian objects or a combination thereof, which would be excessive in relation to the concrete and direct military advantage anticipated.

\section{General Experiences of Military Interventions}

Problems unfolding to IHL were covered extensively after the Cold War as there were multiple internal conflicts especially outside the mainland Europe and the United States of America (USA). Various researches have, in this regard, invested on issues as women's rights, human rights, legality of military interventions, effect of the intervention on the regional peace and security among other issues.

According to Wieruszewski [13], international law, traditionally, recognised the state as "bearers of rights and duties" in international relations. In that study, it was displayed that the Geneva Convention of 1864 as well as the Hague Peace Conference (HPC) of 1899 and 1907 recognised an individual as a beneficiary of state obligation (ibid). The research also shows that there is much specification on the position of the IHL with regard to an individual with particular reference to provisions such as Article III and IV of the 1949 Geneva Convention on the protection of the prisoners of war and the civilian person respectively [11]. Although there are variations between this research and the works by Wieruszewski, the research brings to light a crucial revelation in the field of IHL where the victims of war, particularly the prisoners of war, finds it difficult to enjoy their rights such as the right to "...make request to the military authorities regarding the conditions of captivity" as provided for in Article 78 of the Geneva convention III of 1949 (ICRC 2012). This study, however, considered this aspect as well but looking at it in times of military intervention with reference to the NATO intervention in FRY in 1999.

Mertus [12] in The Global Review of Ethno Politics, was particularly eager to obtain views of human rights activists in countries where interventions were effected. How had military intervention affected civil society? What role had local NGOs played before and after the arrival of foreign troops? Had intervention, in their view, been successful, and how did they measure successes? The report did not, however, assess the effectiveness of the IHL in cases of military intervention which, therefore, became the focus of this paper.

Samantha [3] analysed the doctrine of "humanitarian intervention" and its impact on women in recipient states, particularly with regard to sexual violence. The work, which used the case of Kosovo following the NATO intervention of 1999, presents a challenge to the 'feminist hawks' who are affected by military interventions as they led to situations of methodical sexual violence. The research established that such an intervention would be counterproductive for women's rights and, thus, 
constitute a disproportionate response to sexual violence in terms of international law governing the use of force. Relatedly, Smith and Cuesta [8] assessed the role of peace keeping forces in the formation of human trafficking networks. The research which made reference of the experiences in Kosovo, Haiti and Sierra Leone, shows that there is generally a sharp increase in human trafficking and sexual abuses during presence of foreign military. For instance, in the case of Kosovo, a total of 114 peacekeepers were expelled by the UN after they were found guilty of paying for sex $[8,9]$.

To add on, Smith and Smith [3] note that in 2004, the United Nations Mission in Kosovo's (UNMIK) Trafficking and Prostitution Investigation Unit (TPIU) made a total of 77 arrests, conducted 2,386 raids and assisted 48 victims of human trafficking. The presence of the peacekeeping forces have, therefore, in most parts of Bosnia and Kosovo been associated with the increase and proximity of brothels near the barracks. Human trafficking and sexual violence, therefore, became a renounced effect of foreign military presence in Kosovo. These issues informed the present research but not as core elements as this research concentrated on the direct implications of the NATO bombings on the humanitarian situation in the FRY.

Amnesty International [2] assessed the effectiveness of the EU-led Rule of Law mission in the FRY (EULEX) in dealing with the challenge of impunity in FRY and noted that there was a lot that needed to be done in this regard as the majority of the Serb military forces, police, and paramilitary forces responsible for the war crimes against Kosovo Albanians were not brought to justice. During that period, Amnesty International [15] notes that impunity for crimes involving gender violence continued with only six cases of war crimes having been brought to court by 2002 . The research focused on prosecution of perpetrators of violence in Kosovo but did not include the perpetrators of the NATO induced casualties during the military intervention, a critical aspect of this study.

\section{Methodology}

The study used a qualitative research design to find answers to the research questions. The focus was case specific focussing on the experiences of Kosovo as a province of the former Federal Republic of Yugoslavia (FRY) during the NATO military intervention in 1999. Information used in this study was obtained from international journals, conference reports, text books, newspapers and court rulings. The research utilised content and text analysis to classify the data obtained, thus, established sub headings under which related data was presented. The same was used to give a critical examination of the developments found to have occurred during the military intervention in FRY by NATO forces who participated in Operation Allied Forces (OAF).

\section{Discussion on the findings with regards to the effectiveness of International humanitarian law (IHL) and Operation Allied Force (OAF)}

In order to understand the conduct of NATO forces during OAF, this research, using content and text analysis clustered some of the attacks by NATO forces to examine the extent to which the intervention respected the principles of distinction and proportionality.

\section{An attack on Grdelica railroad bridge (12 April 1999); a bridge in Lužane (01 May 1999); and Varvarin bridge (30 May 1999).}

The incidents involved the attack on communication infrastructure making them, from a general perspective, some military objectives considering the definition of lawful targets that includes transportation (equipment, lines of communication, petroleum, oil, and other lubricants necessary for transport) (Fanrick 2001:494). Although some of these attacks may have been legal military targets, it is important to assess the extent to which the execution of the military attack in these cases did not result in the collateral damage exceeding the military advantage perused by the forces.

The attack on the railroad bridge in question incidentally killed 10 civilians after the dual bombing incidents attacked a scheduled passenger train [5]. This was after the forces attacked the bridge, which was also used as a resupply route for Serb forces in Kosovo. A similar attack occurred when NATO warplanes bombarded the Luzane Bridge during the midday of 1 May 1999. The bridge was a supply link between Nis (Serbia) and Pristina (Kosovo) [5]. AI (2000:46) notes the attack on the bridge resulted in a scheduled civilian bus being a spin-off of the incident and killed 40 people after the bus fell some 60 feet into the riverbank below. The continuation of the air strikes resulted in an ambulance rushing people to a hospital falling victim resulting in one of its medical crews being injured. On the $30^{\text {th }}$ of the same month, another similar attack occurred as the NATO forces attacked the Varvarian 
Bridge in central Serbia at around $1 \mathrm{pm}$. The incident which took place on a market and a religious holiday led to the death of 11 civilians and injure to 40 more civilians.

In the preceding cases, it can be argued that OAF violated the principles of distinction and proportion by failing to consider a number of factors. All the attacks on immobile objects occurred during the day when civilian movement was very high. Again, there was evidence of attacks without guidance of military intelligence as indicated by the derivative attacks on scheduled civilian mobile objects such as the train, the bus and the ambulance. Conducting an attack in a busy market on a scheduled religious holiday was equally wrong and worsened the humanitarian situation in the area under study. Moore to this, NATO forces failed to give an effective warning as required by Article 57(2) (c) of the Additional Protocol 1 of 1977. Giving such warning would, by no means, not jeopardise the effectiveness of the attacks considering that the Serbian authorities could never have moved the bridges in question.

Had NATO carried out its preliminary investigations properly before executing these attacks, it can be argued that different timing could have been opted for only to reduce civilian carnage. Borch [5] notes that NATO argued that the FRY government officials were obliged, under Article 58(c) of the Additional Protocol 1 of 1977 to, "take necessary precautions to protect the civilian population, individual civilians and civilian objects under their control against the dangers resulting from military operations". Failure by the FRY government to protect its civilian population cannot however be used as a justification for the attack on civilian population.

The repeated attacks on civilian objects by NATO forces implies that the intervention failed to play its part the just way. For instance, when an F-15E Strike Eagle of the USA targeted the train at the Grdelica at the first time, the pilot and weapons system officer argued, according to Borch [5], that they only realised there was a train on the bridge when it was too late to stop the laser-guided bomb. That being reasonable, IHL provides that operation should be halted once it is realised that there are civilians at danger. The second strike by the pilot on the same target without proper verification, some few minutes later, shows that the pilot acted negligently by launching the second attack on the same target.

Questionable, again, is the height from which NATO war planes were flying when the attacks were launched. Borch [5] shows that the pilot launched his first laser-guided bomb while still "many miles" from the target, from where he "was not able to put his eyes on the bridge." It can be noted that the average altitude of 15000 feet from which NATO pilots were flying from made it difficult for them to distinguish between military objectives and noncombatants and their property (ibid. 71). Article 57(2) (ii) and (iii) of the 1977 Additional Protocol oblige parties to a conflict to, "take all feasible precautions in the choice of means and methods of attack with view of avoiding, and in any event, minimising incidental loss of civilians." In this regard, flying at that altitude, which later contributed to the increased death toll of the civilians, violated the provisions of laws of armed conflicts. Regrettably, NATO officials argued that the altitude was chosen so as to ensure the safety of the pilots by avoiding surface-to-air missiles [5].

\section{Missile Attack on Serbian Radio and Television Station (Radio Televisija Srbije - RTS) 23 April 1999}

NATO warplanes attacked the Serbian Radio and Television Station (RTS). Franrick [13] pointed at the intentional missile attack at midnight which killed between 10 and 17 civilians who included technicians, security and makeup artist while injuring almost a similar number of civilians. According to AI (2000:40), 120 civilians were in the building at the time of attack. This research obtained that the extent to which the RTS could be considered to be military object was questionable while at the same time the precaution given failed to match he expectations of IHL. According to Voon [7], NATO officially argue that the RTS was a legitimate target. NATO argued that, "the attack was carried out because RTS was a propaganda organ and that propaganda is direct support for military action" (AI 2000: 41).

With regard to this attack, the 1954 Hague Cultural Property Convention (HCPC), one of the critical conventions regulating the conduct of forces in military interventions indicates that broadcast stations may be attacked while the ICRC in a list of military objectives included the installations of broadcasting and television stations provided that they are of fundamental importance [13]. 
The term may, in the 1954 HCPC shows that the object is not an ultimate military objective but may at times be, depending on the situation. The term provided, as used by the ICRC may be interpreted to mean that this can only be attacked if it offers a military advantage. Considering the RTS as a military objective on the basis of it being a propaganda tool can be considered as a baseless argument considering the situation prevailing at the time of the attack.

The judgement given by the International Military Tribunal (IMT) which acquitted Hans Fritzsche, a senior official in the Propaganda Ministry of the 3rd Reich can be used to give clarity on this question. In this case, Franrick [13] noted that the tribunal held that the strong statements of propaganda made by Hans could not be held as a valid reason to consider him as having been a participant in the crimes charged as his aim was to arouse popular sentiments in support of Hitler and not the war. From this point, it can be argued that the RTS could not be considered as a legitimate military attack on ground of it being a propaganda tool for the Milosovic regime. Consequently, this research established that the attack on the RTS was, under IHL, a violation of law. The judgement by the IMT, again, in the Hans case, dovetail with the explanation given by the Committee of the International Criminal Tribunal for the former Federal Republic of Yugoslavia (ICTFRY) which cautioned that,

"had the station gone beyond broadcasting propaganda and actually instructed listeners to kill Albanian Kosovars or engage in other crimes against humanity, it would have become a legitimate military objective" [5].

Having said this, it can be argued, therefore, that the attack on RTS by NATO was a violation of the IHL principle of distinction as the operation intentionally targeted and attacked a civilian object which, according to Gaubatz [14], should be completely immune from the effects of military attack. The attack also violated the principle of proportionality as provided for in Article 57 (2)(c) of Additional Protocol 1 of 1977 by failing to give warning to civilians resulting the casualties caused by an intentional attack on an establishment with 120 civilians

This research also obtained that the warning claimed to have been issued by NATO was not as effective as is required by International Law. Firstly, the contradictions in the statements issued in the public media by the NATO prior to the attack on the $23^{\text {rd }}$ of April are clear testimony of this ineffectiveness. AI [15] notes that on the 8th of April 1999, Air Commodore Wilby stated that NATO had considered RTS a military target as it was used for propaganda and repression. On the same day, General Jean Pierra Kelche, a French armed Force Chief said that NATO was going to, "burst the transmitters and relay stations" as they were considered instruments of propaganda of the Milosevic regime while on 9 April 1999, Jamie Shea, the NATO spokesperson announced that RTS was not among NATO's military targets (ibid).

Contradictory as it is, NATO surprisingly continued to claim that Belgrade's failure to warn its civilian population following the warning given earlier on gives the Serbian government the responsibility for the death of the civilian population as provided for in Article 58 of the Additional Protocol 1. [5]). As indicated by AI [15], Eason Jordan, the president of CNN International confirmed to have received a warning of the attack well before and was advised to tell the CNN people to avoid the TRS. Although this has been used by NATO officials as evidence of an effective warning having been given concerning the attack, Voon [7] vetoed the validity of such warning arguing that:

"If NATO warned CNN and or Yugoslav officials of the attack, it would still arguably fall short of its duty to give 'effective' advance warning. The effectiveness of the warning needs to be judged against whether civilians as a group are made aware of the attack, not just Western civilians."

This observation shows that NATO fell short of its duty to warn the civilians while at the same time the Serbian government can be held liable as it failed to uphold the provisions of Article 58 of 1977 Additional Protocol 1 considering the fact that something was said pertaining to the attack of the RTS by NATO and nothing was done by the Serbian government to protect the Serbian civilian population.

Article 52(2) of the 1997 Additional Protocol 1 provides that a military attack should give a military advantage to the attacker if the attacked object is really a military objective. The military 
advantage gained by NATO following the attack on the RTS, thus, becomes a subject of interest. Authorities such as Bosch [1], Voon [7] and Amnesty International [15] cordially argues that the attack did not give any military advantage required by Article 52 of the Additional Protocol 1 of 1997 to the 1949 Geneva Conventions as few hours following the attack and the death of so many civilians, the facility was back to operation. Surprisingly, NATO forces did not re-attack the facility. In short, it can be argued that the attack on the RTS shows that both the NATO forces as well as the FRY failed to uphold the provisions of the Geneva protocols governing the conduct of hostilities. This therefore shows clearly the extent to which these laws of humanity are violated in cases of military intervention.

\section{Market and Hospital attack at Nis (07 May 1999)}

According to Amnesty International [15], the attacks occurred around mid-day and consist of dropping of cluster bombs in two residential areas of Nis leading to the death of 14 and injure of 30 civilians. NATO argued that this was an incidental loss occurring after the NATO forces misfired and missed its target of the nearby air field.

Although the use of cluster bombs is not prohibited under International Law, Article 51(4) and section (5) of Additional Protocol 1 to the Geneva Convention of 1977 prohibit indiscriminate attacks. The use of this weapon, therefore, shows clearly that NATO forces failed to take measures to spare civilians by taking feasible precautions in the choice of means and methods of attack to avoid or minimise loss of civilian life and refraining from deciding to launch an attack which may cause incidental loss of civilian life as provided for in this Article. Amnesty International [12] notes that NATO admitted that cluster bombs should be used in aerial targets where it should be known that offshoot damage would not occur. Considering the devastating effects of cluster bombs, it become difficult to uphold the principles of distinction when the bomb is used in or near a populated area. The attack on the Korisa village seven days later clearly shows such an effect as 87 civilians lost their lives as outgrowth damage following the dropping of 10 cluster bombs over the village by NATO [7].

The principle of distinctions as provided for in Article 51(8) of the Additional Protocol of 1977 requires that a party to a conflict do give due warning to civilians likely to be harmed by a military attack on a military object. In light of this, the attack on the hospital and a market place at Nis can arguably be considered as having been launched without this consideration. Firstly, the attack occurred during the day when civilian traffic was at peak in the streets. This was after the people had left their bomb cover following a bombing on the air fields which occurred around $0300 \mathrm{hs}$ on the same day [15]. Perhaps, as indicated by Lustgarten and Debrix [16], the conduct of NATO forces in this operation testifies to the argument that forces involved in military interventions sometimes act as if they are beyond the reach of IHL.

In short, it can argued that, of the numerous attacks by NATO during its bombing campaign, the force violated laws regulating the conduct of war. The reason for this argument is, as shown above, the conduct of NATO forces with regard to their interpretation of the law, the means and methods used to select targets, the rules of engagement, precautionary measures taken, the use of specific weapons and the intelligence as it was used to ensure the respect of the principle of distinction. The cases selected and discussed above are just but a drop out of the pool of related cases in which the violations occurred.

\section{Conclusion}

Military interventions, in most cases result in the violation of humanitarian provisions of the international law. Parties taking part in interventions are usually overcrowded by obligations but finally conduct themselves in any possible way to supress the intended enemy without much consideration of the by-product effect of their conduct. Legal provisions of international law requiring for forces to respect the principles of distinction and proportionality are at times difficult to honour during a battle as this may also give advantage to the contesting force.

\section{Recommendation}

Having looked at various aspects of the International Humanitarian law with particular attention on the conduct of the NATO forces in the Federal Republic of Yugoslavia, this paper suggest the following recommendations:

- Parties to every conflict should resorting to peaceful settlement of conflicts as there is no guarantee of civilian safety in military interactions to both the winner and the loser. 
Additionally, the study also recommends for the authorisation for the use of force by the UNSC and is therefore against the decentralisation of such power to allied forces or regional organisations. This argument is based upon a number of factors including the idea that these allied forces or regional organisation have, in most cases, failed to consider the principles of the Jus ad bellom which may be the reason why they fail again to uphold the subsequent Jus in bellom which is the issue at hand;

- Parties taking party in military intervention should do so with a clear mandate. From this, it can be argued that had the UNSC passed a resolution before this attack, the issues of distinction might have been discussed from a legal point of view with the humanitarian concern only to reduce the death toll in form of collateral damage. UNSCR 1244 was only passed after OAF.

- This paper also recommends that there be more legal frameworks that guide military interventions. Although there are a number of international conventions as well as bilateral and multilateral treaties providing for the laws regulating the conduct of war, it is fundamental to note that the 1977 Additional Protocol 1 is the chief on the list. Surprisingly the USA, whose aircraft flew nearly 80 per cent of NATO strike-attack sorties during the campaign, had not ratified the Protocol during OAF. As such, it became difficult to identify the standard of international law which was observed or respected by the member states participating in this bombing campaign [15].

- The adherence to the laws of Geneva by the members of the NATO forces become highly questionable as it appear that the main members of the force do not share a common treaty obligation. From this point of view, it can be argued that the death of the civilian population was exaggerated by the problem that some of these nations did not recognize the provisions of the Additional Protocol 1 of 1977. Voon [7] alludes that NATO must learn from the civilian losses that it imposed in the Kosovo conflict by ensuring that, "all of its member states accede to the Additional Protocol 1." For this reason, the study recommends that for the UN to work hard, through its specialized agencies as well as independent international organizations to lobby for the ratification of the laws regulating the conduct of hostilities not only by NATO members but by all other nations of the world. This, the study believes; will enhance the upholding of such rules, laws and regulations in times of military conflicts.

- Furthermore, a lot need to be done with regard to the aspect of observing the laws available to govern international military action. For example, it is so disappointing to note that UK, regardless of it having ascended to the Additional Protocol 1 of 1977, continued to drop RBL 755 cluster bombs for nearly a month regardless of the condemnation of the condition under which the weapon was being used [15]. Offenders in this regard should therefore never be let off the hook as what happened to the NATO forces as this may have a ripple effect and compromise the future military interventions.

\section{References}

[1] B. Burwitz, Case Study GAL Conference 20-21 March 2009: Kosovo Case HYPERLINK, 2009. [Online]. Available: http://www.ilj.org/GAL/documents/GALch.Burwitz.pdf. [Accessed: March 2020].

[2] Amnesty International, Kosovo: Time for EULEX to Prioritize War Crimes, [Online: amnesty international Ltd], 2012. [Online]. Available: www.amnesty.eu/content/asserts/260412 EULEX.Report.pdf. [Accessed: February 2020].

[3] S. H. Allen and T. Vincen, "Bombing to Bargain? The Air War for Kosovo," University of Mississippi Foreign Policy Analysis (2011), vol. 7, pp. 1-26, 2010. [Online]. Available: http://onlinelibrary.wiley.com/doi/10.1111/j.1743-8594.2010.00120.x/pdf. [Accessed: March 2020].

[4] L. B. Frederic, "Targeting after Kosovo Has the Law Changed for Strike Planners," Naval War College Review, Spring 2003, vol. 56, no. 2, 2003. [Accessed: Februari. 1, 2013].

[5] F. L. Borch, "Targeting After Kosovo: Has the Law Changed for Strike Planners?," Naval War College Review, vol. 56, no. 2, 2003. [Online]. Available: http://www.dtic.mil/cgibin/ GetTRDoc?AD= ADA525034. [Accessed: February 2020]. 
[6] Amnesty International, NATO/Federal Republic of Yugoslavia "Collateral Damage" or Unlawful Killings? Violations of the Laws of War by NATO during Operation Allied Force, 2000. [Online]. Available: http://reliefweb.int/sites/reliefweb.int/files/resources/84AF11F7520 D41B3C12575A100460CE7-Full_Report.pdf. [Accessed: March 2020].

[7] T. Voon, "Pointing the Finger: Civilian Casualties of NATO Bombing in the Kosovo Conflict," American University International Law Review 16, no. 4, pp. 1083-1113, 2001.

[8] C. A. Smith, and B. M. Cuesta, "Human Trafficking in Conflict Zones: The Role of Peacekeepers in the Formation of Networks," Hum Rights Rev, vol. 201, no. 12, pp. 287-299, 2010.

[9] H. McCoubrey, International Humanitarian Law: The Regulation of Armed Conflicts. Aldershot: Dartmouth Publishing Company Limited, 1990.

[10] ICRC, Customary IHL Database, 2018. [Online]. Available: http://.icrc.org/customary.ihl/ eng/docs, 2012. [Accessed: February 2020].

[11] S. Wei, "The Application of Rules Protecting Combatants and Civilians against the Effects of the Employment of Certain Means and Methods of Warfare," in Implementation of International Humanitarian Law, edited by F. Kalshoven and Y. Sandoz. London: Martinus Nijhoff Publishers, pp. 375-394, 1989.

[12] M. Akehurst, A Modern Intriduction to International Law. London: George Allen and Unwin (Publishers) Ltd, 1982.

[13] W. J. Franrick, "Targeting and Proportionality during the NATO Bombing Campaign against Yugoslavia,” EJIL, vol. 12, no. 3, pp. 489-502, 2001. [Online]. Available: http://ejil.org/pdfs/ 12/3/1529.pdf. [Accessed: February 2020].

[14] K. T. Gaubatz, Changing Interests and Persistent Rules: The Protection of Non-Combatants in War. Department of Political Science Stanford University, California, 1999. [Online]. Available: http://kktg.net/kurt/ publications/pubs/Non-Combatants.pdf. [Accessed: February 2020].

[15] Amnesty International, Federal Republic of Yugoslavia "collateral damage" or unlawful killings? Violations of the laws of war by NATO during operation allied force, 2000. [Online]. Available: http://reliefweb.int/sites/reliefweb.int/ files/resources/84AF11F7520D41B3C12575 A100460CE7-Full_Report.pdf. [Accessed: February 2020].

[16] A. Lustgarten, and F. Debrix, "The Role of the Media in Monitoring International Humanitarian Law during Military Interventions," The Case of Kosovo: PEACE \& CHANGE, July Peace History Society and Peace and Justice Studies Association, vol. 30, no. 3, 2005. 